\title{
Knowledge, attitudes, and practices about dengue among pupils from rural schools in an endemic area in Colombia
}

Diana Sarmiento-Senior', María Inés Matiz', Juan Felipe Jaramillo-Gómez', Víctor Alberto Olano ${ }^{1}$, Sandra Lucía Vargas ${ }^{1}$, Neal Alexander ${ }^{2}$, Audrey Lenhart ${ }^{3}$, Thor Axel Stenström4, Hans Jörgen Overgaard 5

${ }^{1}$ Instituto de Salud y Ambiente, Universidad El Bosque, Bogotá, D.C., Colombia

${ }^{2}$ MRC Tropical Epidemiology Group, London School of Hygiene and Tropical Medicine, London, United Kingdom

${ }^{3}$ Liverpool School of Tropical Medicine, Liverpool, United Kingdom

${ }^{4}$ Institute for Water and Wastewater Technology, Durban University of Technology, Durban, South Africa

${ }^{5}$ Faculty of Science and Technology, Norwegian University of Life Sciences, Ås, Norway

Introduction: Dengue is a public health problem in tropical and subtropical regions of the world. Studies on dengue in rural areas are scarce since the disease is considered mainly urban.

Objective: To determine the knowledge $(K)$, attitudes $(A)$ and practices $(P)$ of dengue in an endemic area in Colombia.

Materials and methods: We conducted a cross-sectional study with 515 pupils (7-16 years old) in 34 rural schools in Anapoima and La Mesa municipalities during 2011. Each KAP category was evaluated independently by a scoring system and then categorized into high, medium or low.

Results: Pupils recognized knowledge variables such as the symptoms (fever, bone pain), transmission route (mosquito bites), and mosquito breeding sites (uncovered water tanks, solid waste). Average scores on attitude were high in both municipalities indicating a well-developed perception of disease severity. Seeking treatment in medical centers and self-medication for fever management and the use of mosquito net and space-spraying of insecticides were the most frequently identified practices.

Received: $25 / 01 / 18$

Accepted: $25 / 10 / 18$

Published: $17 / 12 / 18$

\section{Citation:}

Sarmiento-Senior D, Matiz MI, Jaramillo-Gómez JF, Olano VA, Vargas SL, Alexander N, et al. Knowledge attitudes, and practices about dengue among pupils from rural schools in an endemic area in Colombia. Biomédica. 2019;39:478-90.

https://doi.org/10.7705/biomedica.4255

Corresponding author:

Diana Marcela Sarmiento-Senior, Instituto Salud y Ambiente, Universidad El Bosque, Calle $131 \mathrm{~N}^{\circ} 7 \mathrm{~A}-$ 68, Bogotá, D.C., Colombia

Telephone: (571) 648 9000; extension 1164 and 1181 sarmientodiana@unbosque.edu.co

Author contributions:

Diana Sarmiento: Data collection, analysis and interpretation and manuscript drafting

María Inés Matiz, Juan Felipe Jaramillo-Gómez, Víctor Alberto Olano and Sandra Lucía Vargas: Data collection and manuscript drafting

Neal Alexander and Hans Jörgen Overgaard: Data analysis and interpretation and manuscript drafting Audrey Lenhart and Thor Axel Stenström: Revision of the manuscript, final approval of the version, and accountability for all aspects of the work

All authors participated in the design of the study.

Funding:

The Research Council of Norway (Grant 201349), Universidad El Bosque, and the Lazos de Calandaima Foundation supported financially the project.

Conflicts of interest:

The authors have declared that no competing interests exist.
Discussion: This is the first KAP dengue study performed in a rural area in Colombia and as such it contributes to the understanding of dengue perceptions by the inhabitants of these areas. It showed a medium level of knowledge about dengue and a lower level of preventive practices in pupils from rural schools. It also showed that pupils considered space-spraying as crucial for vector control. The presence of the vector in rural areas of the country underlines the need to improve surveillance and education to more effectively control the vector and promote prevention methods including community participation.

Keywords: Dengue/prevention \& control; health knowledge attitudes practice; rural health; ethnology; Colombia.

Conocimientos, actitudes y prácticas sobre dengue en estudiantes de escuelas rurales de un área endémica en Colombia

Introducción. El dengue es un problema de salud pública en las regiones tropicales y subtropicales del mundo. Los estudios sobre la enfermedad en áreas rurales son escasos debido a que se presenta principalmente en los núcleos urbanos.

Objetivo. Determinar los conocimientos, las actitudes y las prácticas sobre el dengue en un área rural endémica en Colombia.

Materiales y métodos. Se hizo un estudio transversal con 515 estudiantes, entre los 7 y los 16 años de edad en 34 escuelas rurales de los municipios de Anapoima y La Mesa en el 2011. Cada categoría se evaluó por separado con un puntaje clasificado como alto, medio o bajo.

Resultados. Los estudiantes reconocieron los síntomas (fiebre, dolor de huesos), la ruta de transmisión (picadura de mosquitos) y los criaderos (depósitos de agua destapados, residuos sólidos). El promedio de los puntajes de actitudes fue alto en ambos municipios, lo que indica que percibían la gravedad del dengue. Las prácticas más frecuentes de tratamiento de la fiebre fueron la consulta médica y la automedicación, en tanto que los métodos de control más frecuentes fueron el uso de mosquiteros y el rociamiento con insecticidas.

Discusión. Este es el primer estudio de conocimientos, actitudes y prácticas sobre el dengue en un área rural de Colombia. Los resultados contribuyen a entender las percepciones de la enfermedad en sus habitantes y evidenciaron niveles medios de conocimiento y puntuaciones bajas en cuanto a las prácticas entre los estudiantes de las escuelas rurales. Los estudiantes consideraron que la fumigación es importante para el 
control del vector. La presencia del mosquito en áreas rurales del país resalta la necesidad de mejorar la vigilancia y la educación para lograr un control efectivo del vector y promover métodos de prevención que incluyan la participación comunitaria.

Palabras clave: dengue/prevención y control; conocimientos, actitudes y práctica en salud; salud rural; etnología; Colombia.

Dengue is a serious and increasing public health problem in tropical and subtropical regions of the world (1) with approximately 3,900 million people at risk of infection (2), around 390 million annual infections, and 96 million presenting clinical signs (3). In 2010, Colombia experienced its worst-ever epidemic with more than 157,000 reported cases and 217 deaths. Anapoima and La Mesa municipalities in the department of Cundinamarca were classified as very high-risk areas based on their number of cases (4).

Among the determinants of the increasing incidence are the simultaneous circulation of four serotypes (5), the lack of continuous water supply, poor or inadequate solid waste management, unplanned urban growth, internal displacement, and poverty (4). Besides, the situation is worsened by climatic variations such as EI Niño and La Niña phenomena that can make conditions more favorable for the main vectors Aedes aegypti and $A$. albopictus and disease transmission (4). Recently, the circulation of other viruses such as chikungunya and Zika may have contributed to an underestimation of dengue through misdiagnosis due to their similarity of symptoms and the high cost of laboratory tests that hinder their application in every case (6).

Although the World Health Organization (WHO) recommended a vaccine as part of an integrated dengue prevention and control strategy (7), there is no dengue vaccination program in Colombia. The only preventive measures available are based on mosquito control, which is highly dependent on community participation (8). In recent decades, this has been increasingly recognized and acknowledged in studies on integrated dengue interventions linking local human populations and their practices on prevention and vector control $(9,10)$.

The need to determine how knowledge about the disease is related to prevention practices has been highlighted in community and school guides and reports (9). However, information strategies do not always change behaviors, such as the elimination of domestic breeding sites (11), sometimes because recommended practices are neither well-suited to existing habits nor adapted to the socio-economic conditions of the communities $(11,12)$.

Educational institutions can function as training centers and meeting sites for communities from which health education, productive projects, and new technologies can be disseminated $(8,13-16)$. Some dengue prevention initiatives have used schools as points of community communication and assessed knowledge, attitudes, and practices (KAP) of pupils, their families or their communities (14-16). However, such KAP studies are scarce in rural areas, since dengue transmission is considered mainly urban $(4,10)$. Nevertheless, $A$. aegypti is present in rural areas, sometimes with high virus infectivity suggesting active transmission $(5,17)$.

The present study was part of the baseline work of a trial of integrated interventions for preventing dengue and diarrhea in rural Colombian schools (18). The objective was to determine the KAP about dengue among pupils in grades 2 to 5 in rural schools in Anapoima and La Mesa municipalities in Cundinamarca department. 


\section{Materials and methods}

We conducted a cross-sectional study in rural schools $(<100$ pupils and $\leq 5$ grades) of Anapoima and La Mesa, 17 schools in each municipality (figure 1); 828 pupils were eligible to participate in the study according to the records of the schools. KAP surveys were performed from May to June 2011 with 515 pupils in grades 2 to 5: 309 in La Mesa and 206 in Anapoima (table 1).

\section{Study area}

Anapoima has an average altitude of 700 meters above sea level, a mean temperature of $26^{\circ} \mathrm{C}$, an area of $124.2 \mathrm{~km}^{2}$, and a population of 12,539 inhabitants (56\% rural) $(19,20)$. La Mesa is 1,200 meters above sea level, its mean temperature is $22^{\circ} \mathrm{C}$, it has an area of $148 \mathrm{~km}^{2}$, and 29,566 inhabitants $(45 \%$ rural) $(20,21)$. The mean annual rainfall is $1,300 \mathrm{~mm}$ in both municipalities.

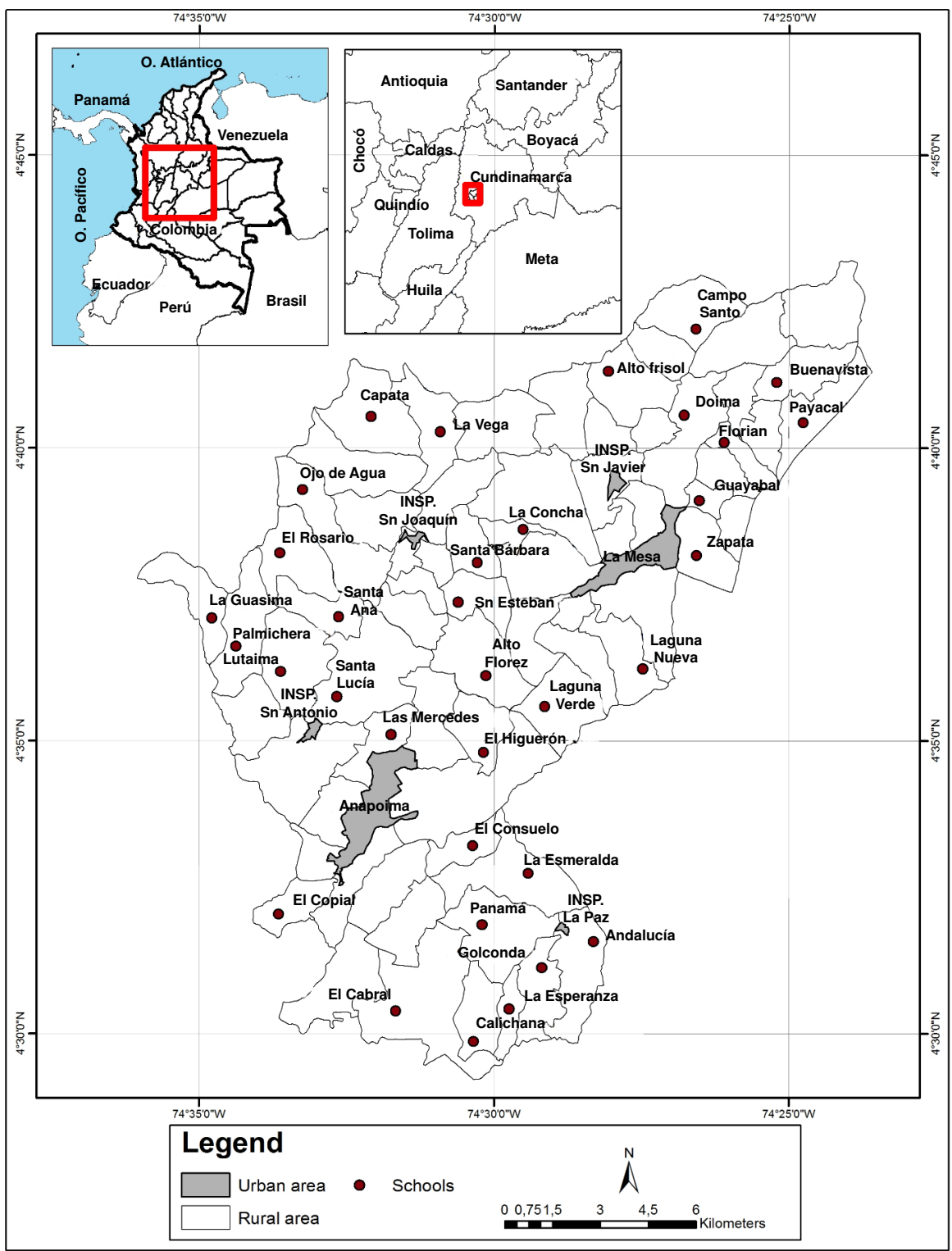

Figure 1. Location of the sampled rural schools in Anapoima and La Mesa municipalities 
Table 1. Description of the pupils surveyed in Anapoima and La Mesa municipalities in 2011

\begin{tabular}{lrrrrrr}
\hline \multirow{2}{*}{ Variable } & \multicolumn{2}{c}{ Anapoima } & \multicolumn{2}{c}{ La Mesa } & \multicolumn{2}{c}{ Total } \\
& $\mathbf{n}$ & $\%$ & $\mathbf{n}$ & $\%$ & $\mathbf{n}$ & $\%$ \\
\hline Total number of pupils in the study & 206 & 40 & 309 & 60 & 515 & 100 \\
Mean pupil age (in years) (SD) & $9.4(1.6)$ & & $9.3(1.7)$ & & $9.3(1.7)$ & \\
Age range (in years) & $7-16$ & & $6-14$ & & $6-16$ & \\
Female population & 86 & 41.7 & 138 & 44.7 & 224 & 43.5 \\
Male population & 120 & 58.3 & 171 & 55.3 & 291 & 56.5 \\
2nd grade & 51 & 24.8 & 74 & 23.9 & 125 & 24.3 \\
3rd grade & 47 & 22.8 & 86 & 27.8 & 133 & 25.8 \\
4th grade & 50 & 24.3 & 81 & 26.2 & 131 & 25.4 \\
5th grade & 58 & 28.2 & 68 & 22.0 & 126 & 24.5 \\
\hline
\end{tabular}

The main economic activities are tourism and agriculture based on sugar cane, coffee, and fruit tree crops, as well as livestock. In 2010, the proportion of people with unmet basic needs (UBN), an indicator of poverty, in the rural areas of Anapoima was $36.4 \%$, while in the urban areas it was $21.2 \%$ (19). In La Mesa, the proportions were $36.8 \%$ and $11.8 \%$, respectively (21). Anapoima has a lower average altitude and a higher proportion of rural population. Nevertheless, La Mesa has a larger rural area. Both municipalities were classified as very highrisk areas based on their number of cases of dengue in the last 15 years (4).

\section{Data collection}

A questionnaire in Spanish was developed, field-tested and reviewed by experts in education, epidemiology, and entomology. The language was chosen to optimize comprehension and clarity considering the target age group. A member of the project attended readings with groups of up to five pupils in grades 2 and 3 . This person read and showed the questions and response options ensuring that all items were answered without inducing answers. Pupils in grades 4 and 5 read the questionnaire independently without intervention from other pupils or project staff. Two or more members of the project team accompanied each group, which had at most 15 pupils.

The questionnaire consisted of six multiple-choice questions, three for establishing knowledge about dengue, one for attitudes and two for prevention practices. Knowledge of the symptoms of dengue, its mode of transmission, and identification of four mosquito breeding sites (laundry tanks or albercas -large concrete tanks used for storing water for laundry, one of the most common breeding sites in the area-, tires, uncovered water tanks, solid waste) were evaluated. The question regarding attitudes related to disease severity. As for practices, the pupil was asked about fever management and measures for dengue prevention and control. The identification of practices for fever management by pupils was included in the practices section considering that children usually receive care from adults. Additional variables included age, sex, grade, and municipality. The questionnaire was delivered to pupils in the target age group (grades 2-5) present in the school who were able to read and write, without cognitive disabilities, and who had provided parental consent (oral or written) and personal assent (oral or written).

\section{Analysis}

Individual scores were calculated for the knowledge, attitudes and practices sections and then scaled to a range of 0 to 10 . Values for each student were used to calculate averages by school and municipality. For the knowledge and practice scales, categories were divided into quartiles 
and classified into three groups (high, medium, and low) by combining the two groups below the $50^{\text {th }}$ percentile. For the knowledge scale, the low quartile was $<6.6$, the medium between 6.6 and 8.3 , and the high $>8.3$. The corresponding figures for the scale of practices were $<5.4,5.4-7.2$, and $>7.3$. A scale for attitudes was not developed because the only possible values were zero or ten.

To determine the homogeneity of variance, Fisher $\mathrm{F}$ tests were performed where if the $p$ value was greater than 0.05 , the assumption of equal variances was considered valid. Student's $t$ test for independent groups was used to compare mean scores by municipality, where a $p$ value of $<0.05$ was considered statistically significant. The Huber-White estimator of the covariance matrix was used to allow for clustering within schools.

The KAP surveys data were entered and cleaned in Microsoft Excel ${ }^{\mathrm{TM}}$, version 2010, and analyzed in Epidat ${ }^{\mathrm{TM}}$, version 3.1, and R, version 3.1.1, including the package 'rms'.

\section{Ethical considerations}

Based on national regulations, the study was classified as minimal risk (22). The institutional research ethics committee of Universidad El Bosque, Bogotá, Colombia (Minutes No. 146 of 30/08/2 011) and the Ethical Review Board of the London School of Hygiene and Tropical Medicine (Ref. No. 10 453(6 289)-1) approved the study. Directors and teachers of the schools gave written consent. Written consent of parents and written assent were sought for all pupils enrolled. Assent was sought from pupils after it was explained that participating or not would have no academic or disciplinary implications. Only those giving oral assent participated in the survey.

\section{Results}

\section{Description of the population}

Out of the total population of pupils reported as enrolled in the rural schools, $62.2 \%(n=515)$ participated in the survey. Sixty percent of pupils in the sample lived in La Mesa municipality and the remainder in Anapoima. The average age was 9.3 years (SD=1.7), 9.4 for males and 9.2 for females. The majority were male with $58 \%$ in Anapoima and $55 \%$ in La Mesa. The largest group was the fifth grade in Anapoima and the third grade in La Mesa, each representing approximately $28 \%$ of the surveyed population (table 1 ).

\section{Knowledge}

The average knowledge score was significantly higher in Anapoima than in La Mesa, 7.2 (95\% confidence interval [95\% Cl]: 6.9-7.5) and $5.6(95 \% \mathrm{Cl}$ : 5.3-5.9), respectively (t[513]= -8.0, $p<0.001$ ) (figure 2). In Anapoima, 3 of 17 schools reached a high-level score (above 8.3), and 9 of 17 schools reached the medium level. In La Mesa, just one school achieved a medium score while the remaining 16 schools were in the low category.

A set of manifestations for dengue disease such as fever, bone pain, red spots on the skin, and bleeding from the nose and gums were identified by 87 $(17 \%)$ of the pupils. The most frequently recognized dengue symptoms were fever (56\% La Mesa, 74\% Anapoima) and bone pain (48\% La Mesa, 64\% Anapoima) (table 2). Mosquito bite was the transmission route selected by $87 \%$ of the pupils ( $85 \%$ La Mesa, $91 \%$ Anapoima). Overall, $116(23 \%)$ of the 
respondents identified all the four options for potential breeding sites of the dengue vector. Considering both municipalities together, the most frequently identified breeding sites were uncovered water tanks (68\%) and solid waste (59\%). Eighty percent of the pupils in Anapoima and only $40 \%$ of pupils in La Mesa identified washbasins (albercas) as breeding sites (table 2).

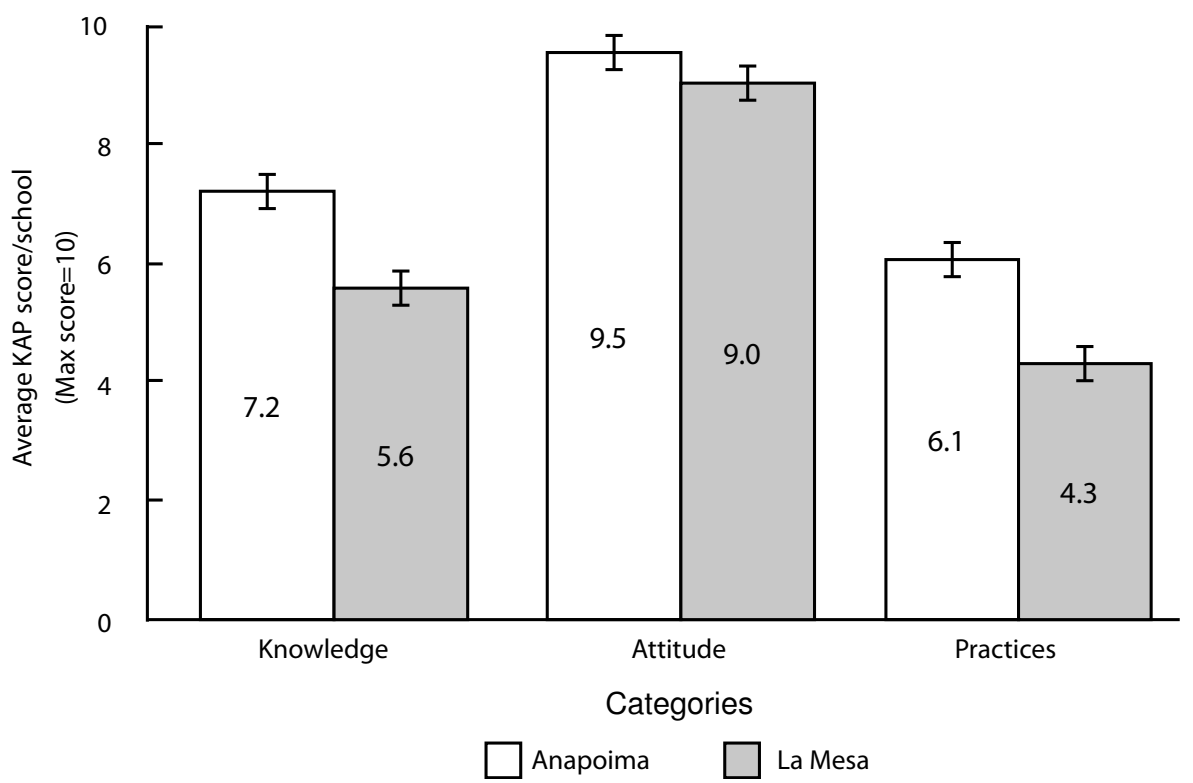

Figure 2. Knowledge, attitudes, and practices (KAP) about dengue in pupils in rural primary schools in Anapoima and La Mesa municipalities, Cundinamarca department, Colombia, 2011. Error bars indicate $95 \%$ confidence intervals.

Table 2. Number and percentage of pupils with knowledge about dengue symptoms, transmission routes, and mosquito breeding sites in rural schools in Anapoima and La Mesa municipalities, Cundinamarca department, Colombia, 2011

\begin{tabular}{lrrrrrr}
\hline & \multicolumn{2}{c}{ Anapoima } & \multicolumn{2}{c}{ La Mesa } & \multicolumn{2}{c}{ Total } \\
& $\mathbf{n = 2 0 6}$ & $\%$ & $\mathbf{n = 3 0 9}$ & $\%$ & $\mathbf{n = 5 1 5}$ & $\%$ \\
\hline Symptoms & & & & & & \\
$\quad$ Fever & 152 & 73.8 & 173 & 56.0 & 325 & 63.1 \\
$\quad$ Bone pain & 131 & 63.6 & 148 & 47.9 & 279 & 54.2 \\
$\quad$ Bleeding from the nose and gums & 131 & 63.6 & 94 & 30.4 & 225 & 43.7 \\
$\quad$ Red spots on the skin & 128 & 62.1 & 92 & 29.8 & 220 & 42.7 \\
Transmission route & & & & & & \\
$\quad$ Mosquito bite & 187 & 90.8 & 263 & 85.1 & 450 & 87.4 \\
$\quad$ Proximity to someone sick & 29 & 14.1 & 94 & 30.4 & 123 & 23.9 \\
$\quad$ Via food & 9 & 4.4 & 4 & 1.3 & 13 & 2.5 \\
Breeding sites & & & & & & \\
$\quad$ Uncovered water tanks & 161 & 78.2 & 189 & 61.2 & 350 & 68.0 \\
$\quad$ Solid waste & 119 & 57.8 & 183 & 59.2 & 302 & 58.6 \\
$\quad$ Washbasins (albercas) & 165 & 80.1 & 124 & 40.1 & 289 & 56.1 \\
$\quad$ Tires & 141 & 68.4 & 100 & 32.4 & 241 & 46.8 \\
\hline
\end{tabular}

\section{Attitudes}

The overall perception of disease severity revealed that $92 \%$ of pupils (Anapoima 95\%, La Mesa 90\%) thought that dengue is a health problem for them. There was no significant difference between Anapoima and La Mesa, 9.5 (95\% Cl: 9.2-9.8) and 9 (95\% Cl: 8.7-9.3), respectively (t[504]=1.9, $\mathrm{p}=0.16$ ) (figure 2). 


\section{Practices}

The pupils from Anapoima had a significantly higher average score than those from La Mesa, 6.1 (95\% Cl: 5.8-6.4) and 4.3 (95\% Cl: 4-4.6), respectively (t[488]=-8.3, $\mathrm{p}<0.001$ ) (figure 2 ). Anapoima's average score was in the medium category while La Mesa's was low. The main practices for fever management identified among the seven options given were seeking care at a medical center (Anapoima 82\%, La Mesa 72\%), and taking medication (Anapoima 69\%, La Mesa 65\%). Other practices that pupils identified were the use of mosquito nets and receiving herbal infusions (table 3 ).

Table 3. Number and percentage of pupils identifying practices for fever management and dengue prevention and control in rural schools in Anapoima and La Mesa municipalities, Cundinamarca department, Colombia, 2011

\begin{tabular}{|c|c|c|c|c|c|c|}
\hline & \multicolumn{2}{|c|}{ Anapoima } & \multicolumn{2}{|c|}{ La Mesa } & \multicolumn{2}{|c|}{ Total } \\
\hline & $\mathrm{n}=\mathbf{2 0 6}$ & $\%$ & $n=309$ & $\%$ & $n=515$ & $\%$ \\
\hline \multicolumn{7}{|l|}{ Practices for fever management } \\
\hline Going to the medical center & 169 & 82.0 & 222 & 71.8 & 391 & 75.9 \\
\hline Taking medication & 142 & 68.9 & 200 & 64.7 & 342 & 66.4 \\
\hline Using mosquito net & 108 & 52.4 & 89 & 28.8 & 197 & 38.3 \\
\hline Receiving herbal infusions & 83 & 40.3 & 92 & 29.8 & 175 & 34.0 \\
\hline Bathing and refreshing & 64 & 31.1 & 102 & 33.0 & 166 & 32.2 \\
\hline Drinking water and abundant liquids & 66 & 32.0 & 88 & 28.5 & 154 & 29.9 \\
\hline \multicolumn{7}{|l|}{ Actions for dengue prevention and control } \\
\hline Using mosquito net & 170 & 82.5 & 195 & 63.1 & 365 & 70.9 \\
\hline Fumigation with insecticides & 149 & 72.3 & 208 & 67.3 & 357 & 69.3 \\
\hline Washing albercas & 162 & 78.6 & 142 & 46.0 & 304 & 59.0 \\
\hline Changing water of vases & 160 & 77.7 & 138 & 44.7 & 298 & 57.9 \\
\hline Taking out water of tires & 155 & 75.2 & 129 & 41.7 & 284 & 55.1 \\
\hline Covering water containers & 140 & 68.0 & 145 & 46.9 & 285 & 55.3 \\
\hline Learning and teaching & 28 & 13.6 & 23 & 7.4 & 51 & 10 \\
\hline
\end{tabular}

albercas: large concrete tanks used for storing water for laundry

Among the actions to be taken to avoid the disease, the most common answer in both municipalities was the use of mosquito nets (Anapoima $83 \%$, La Mesa 63\%). Other practices considered important in La Mesa were space-spraying of insecticides and covering water storage containers while in Anapoima, respondents said washing the albercas and changing the water in floral vases (table 3).

\section{Discussion}

In this study, we determined KAP among pupils in rural schools in Anapoima and La Mesa municipalities. Overall, we found a medium level of knowledge about dengue and a lower level of preventive practices in both municipalities. While schools, health institutions or media mainly promote knowledge, practices to control the vector depend on many factors such as infrastructure, socio-economic conditions, demographic characteristics, and personal choice (23-25).

Although the national surveillance public health policy defines activities for dengue prevention and control (26), the regular vector control strategies adopted by local health boards may differ between municipalities. During an epidemic, it is mandatory to stop transmission according to the national protocol; municipalities also carry out complementary actions such as solid waste collection campaigns in critical areas. Despite being neighbors, the two municipalities in this study differ in terms of altitude and proportion of 
rural areas and population, which may affect decisions on vector control strategies and the activities that are recognized by inhabitants. Anapoima experienced higher dengue incidence than La Mesa in 2010 (Anapoima: 3,198 per 100,000 population vs. La Mesa: 1,975 per 100,000 population) and in 2011 (Anapoima: 679 per 100,000 population vs. La Mesa 160 per 100,000 population) (27). Higher scores in knowledge and practices of pupils from Anapoima may have been influenced by the delivery of an educational intervention in the municipality for prevention and control of dengue with community agents in rural areas in 2010 (28), as well as municipal education campaigns as a response to the high incidence of dengue.

Nevertheless, these activities usually focused on urban areas (18).

Comparable studies in rural areas of Colombia are scarce since dengue is mainly considered an urban disease $(4,10)$. However, greater attention has recently been given to the occurrence of the disease in rural areas showing vector presence, rural infections $(17,23,29)$, and the presence of the virus in the vector (5). Our study, therefore, adds valuable new information on awareness and practices, which is relevant for the planning of disease prevention programs. However, a consensus needs to be reached on measurement methods for knowledge, attitudes, and practices to allow comparison of results.

\section{Knowledge}

Thirty percent of the pupils in Anapoima identified a combination of disease manifestations compared to only $8 \%$ in La Mesa. Other studies conducted in urban primary schools in Latin America found that $77 \%$ of pupils in Honduras (16), $41 \%$ in Brazil (13), and $42 \%$ in México (30) identified dengue symptoms such as fever, bone pain, and red spots on the skin when asked what it feels like to have dengue. KAP studies can be compared across age and school grade, but results have to be interpreted carefully because of differences between populations, socioeconomic status, and health surveillance determining urban and rural conditions.

Eighty-seven percent of the pupils identified that the disease is transmitted by mosquito bite, similar to $92 \%$ in the Philippines (23) and $97 \%$ in Malaysia (29). Despite the young age of the pupils in this study, their knowledge of this aspect exceeded two previous Latin American studies, which found that $68 \%$ of pupils surveyed in Honduras (16) and $56 \%$ in México (30) knew that mosquitoes transmit dengue. Better identification of the mode of transmission may be related to the strengthening of mass media messages in recent years (8). Moreover, actions for prevention and control carried out by public health programs and entomological surveillance have increased (26). Inhabitants of these areas are in constant contact with the disease, which facilitates learning from their own experiences or through contact with health staff (12). Overall, $24 \%$ of the pupils said that dengue can be transmitted by proximity to someone who is sick, a high proportion compared to $14 \%$ reported by pupils in an urban location in Colombia (15). Few KAP studies on dengue report other answers than mosquito bites being the main route of transmission. However, qualitative approaches have identified that some populations think of the disease as an everyday illness or associate it with common cold (12).

Just $23 \%$ of the pupils in our study recognized all the four given breeding sites, in contrast to $68 \%$ of pupils in Honduras (16) and $49 \%$ in México (30) asked to identify three. Only $40 \%$ of pupils in La Mesa identified the alberca 
as a breeding site, although this is a common $A$. aegypti breeding site $(12,31)$. Their elimination as breeding sites is hindered by their large volume and lack of an efficient way to seal them (31). Only $61.2 \%$ of rural areas in Colombia have access to regular piped water supply (32), which forces inhabitants to store water in containers potentially providing breeding sites for the vector. Some studies identified a lack of accuracy in the knowledge related to breeding places and more appropriate water storage methods as important themes for community education to focus on (25).

A majority of pupils in our study identified solid waste as a breeding site for the mosquito that transmits dengue. We found that $59 \%$ of the pupils associated solid waste with the mosquito while a study conducted in Brazil showed that $78 \%$ of the general population did so (25). Where appropriate rubbish collection practices and programs are lacking, people dispose of waste in open fields.

\section{Attitudes}

Pupils from both municipalities expressed a high level of concern regarding the risk of dengue. Pupils in La Mesa recognized the risk to a slightly lesser extent (90\%) than the ones in Anapoima (95\%), although the difference was not statistically significant. Our results are similar to those of other studies, which found that dengue and its risks are a matter of concern for communities $(25,33)$. Measuring attitudes related to the disease should be strengthened, and questionnaires should be supplemented with qualitative approaches $(11,12,25,30)$.

\section{Practices}

The average scores of practices were significantly higher in Anapoima than in La Mesa. We asked pupils about fever management practices of adults. Even though pupils were not directly guiding these practices due to their age, we asked them to identify the typical procedures undertaken by their parents and caregivers. They reported seeking help at a medical center (76\%) as a fever management practice similar to results from comparable studies in Latin America $(29,33)$. Strategies like home care or self-medication (12) were the second most common response, which is reasonable considering existing poor roads, scarce means of transport, availability of health systems in rural areas, difficulties in accessing medical services, and parents' consideration that illness is not severe enough to seek help at a medical center $(12,25)$. Although seeking help at a medical center was the most frequent answer, it has been shown that some families choose home care at the beginning of the disease (12).

Our study also included domestic fever management practices such as herbal infusions (34\%) and fluid administration (30\%). These have seldom been included in other studies (11). Mass-media campaigns generally focus on information about community vector control, although there is a real need to improve knowledge about the disease and home care of infected persons (34).

A notable finding is the relatively low percentage of pupils that identified the use of mosquito net as a prevention measure during fever episodes (overall 38\%). The use of mosquito nets for dengue prevention is generally low in Colombia although health authorities promote their use by sick people in endemic areas to avoid onward dengue transmission (10). In fact, national health authorities in Colombia recommend the use of mosquito nets as an 
individual strategy to prevent the transmission of the disease in households and hospitals during the first eight days of fever (35). However, this did not seem to be clearly recognized in our study. Data from urban areas showed that $6 \%$ in Carepa and Apartadó (Antioquia department) (34) and 28\% in Bucaramanga (Santander department) (33) reported using nets against dengue. This is different from a rural area in the Philippines, where $59 \%$ of the population used nets for protection against dengue (23). The emphasis of educational and vector control interventions on container management rather than home care could be a reason for the low recognition of this strategy $(34,36)$.

Space-spraying of insecticides was the second most common choice for prevention. Several studies have shown that inhabitants perceive space-spraying as crucial for vector control $(12,24,34,36)$. The intensive use of insecticides by health authorities can hinder the implementation of other preventive interventions because it can lead communities to downplay their responsibility or the impact of their practices in prevention (24). The ranking of control methods identified in La Mesa could reflect the familiarity of the pupils with these procedures, as well as the low identification of other prevention methods.

Overall, $55 \%$ of pupils in our study recognized that covering water containers is a strategy to prevent and control dengue. We consider this percentage to be low given how central the activity is to dengue control. Sixtyfive percent of pupils in Medellín (15) and $72 \%$ of pupils in Puerto Rico (14) identified breeding site reduction as a dengue intervention.

Considering the weaknesses found in previous interventions, education plans adapted to community interests and resources are needed $(12,15,25)$. Participatory approaches from the design stage of the intervention can motivate people to get involved in changing risk behaviors. Education from an early age is a key factor in people's understanding of the disease and the implementation of risk-reducing practices $(24,36)$.

Where appropriate, the school curriculum should include these educational processes acknowledging rural conditions. This may lead to applicable preventive measures and play-based strategies (14-16,33). When assessing knowledge gaps, it is important to make distinctions based on, for example, age, educational level, and urban/rural settings. The distinction between academic and applicable knowledge in the everyday lives of rural inhabitants and the relationship to socio-economic constraints must be acknowledged.

It is necessary to focus on rural residents' concepts of illness, awareness of the disease, use of space-spraying only in emergencies, and actions, especially self-medication and use of mosquito nets for home care of children, infants and the sick in general. Despite having a basic knowledge of the disease, the individuals and the community have yet to fully transform this knowledge into protective practices. Hence, it is imperative to link academia and the government to strengthen community action through the improvement of the water, sanitation and health infrastructure, as well as the innovative use of resources and capacities for long-term inter-sector interventions $(34,36)$.

Few KAP studies have been performed in rural Colombia since dengue is mainly considered an urban disease. To our knowledge, this is the first dengue KAP study in a rural area in the country. The recent evidence of the presence of $A$. aegypti and the virus in rural areas requires improved entomological and epidemiological surveillance, as well as educational programs oriented to both pupils and community members. 
Good knowledge does not guarantee its transformation into better practices, especially if there is a lack of stimuli, insufficient water, sanitation and health infrastructure development, and low community participation.

Pupils demonstrated a good knowledge of the transmission route of dengue while knowledge of symptoms and breeding sites was mixed indicating the need to strengthen this knowledge from an early age. Results on practices showed ambivalence on the use of mosquito nets and low percentages identifying the covering of water containers as a preventive strategy, also, a high tendency for self-medication. There remains a need to measure preventive practices in rural areas and identify remaining barriers to their implementation.

\section{Acknowledgements}

Authorities of Anapoima and La Mesa helped during the process. We thank directors, teachers, and pupils for their joy and participation and Luz Marina Contreras, Laura Cabezas, Esmeralda González, Humberto Mosquera, Nancy Herrera, Rosa Silva, Rosa Pulido, Paola Moreno, and Sandra Moreno for their fieldwork; Edgar Ibáñez for the initial statistical support, Laura Cabezas, for the site map and Dr. Miguel Otero, for his support as Vice-President of Research at Universidad El Bosque.

\section{References}

1. World Health Organization. Dengue and severe dengue. Geneva: World Health Organization; 2016. Accessed on: May 27, 2016. Available at: http://www.who.int/ mediacentre/factsheets/fs117/en/

2. Brady OJ, Gething PW, Bhatt S, Messina JP, Brownstein JS, Hoen AG, et al. Refining the global spatial limits of dengue virus transmission by evidence-based consensus. PLoS Negl Trop Dis. 2012;6:e1760. https://doi.org/10.1371/journal.pntd.0001760

3. Bhatt S, Gething PW, Brady OJ, Messina JP, Farlow AW, Moyes CL, et al. The global distribution and burden of dengue. Nature. 2013;496:504-7. https://doi.org/10.1038/nature12060

4. Padilla J, Rojas D, Sáenz-Gómez R. Dengue en Colombia: epidemiología de la reemergencia a la hiperendemia. Bogotá: Guías de impresión; 2012.

5. Pérez-Castro R, Castellanos JE, Olano VA, Matiz MI, Jaramillo JF, Vargas SL, et al. Detection of all four dengue serotypes in Aedes aegypti female mosquitoes collected in a rural area in Colombia. Mem Inst Oswaldo Cruz. 2016;111:233-40. https://doi.org/10.1590/0074-02760150363

6. Christofferson RC. Zika virus emergence and expansion: Lessons learned from dengue and chikungunya may not provide all the answers. Am J Trop Med Hyg 2016;95:15-8. https://doi.org/10.4269/ajtmh.15-0866

7. World Health Organization. Dengue vaccine: WHO position paper - September 2018. Weekly Epidemiol Record. 2018;36:457-76.

8. Elder J, Lloyd L. Achieving behaviour changes for dengue control: Methods scaling-up and sustainability. Report of the Scientific Working Group on Dengue. Geneva: World Health Organization; 2006.

9. Heintze C, Garrido MV, Kroeger A. What do community-based dengue control programmes achieve? A systematic review of published evaluations. Trans R Soc Trop Med Hyg. 2007;101:317-25. https://doi.org/10.1016/..trstmh.2006.08.007

10. Organización Mundial de la Salud, Organización Panamericana de la Salud. Dengue: Guías para el diagnóstico, tratamiento, prevención y control. Primera edición. La Paz: OPS/OMS; 2009.

11. Claro LB, Kawa H, Cavalini LT, Rosa ML. Community participation in dengue control in Brazil. Dengue Bulletin. 2006;30:214-22.

12. Suárez R, Olarte S MF, Ana MF, González C. Is what I have just a cold or is it dengue? Addressing the gap between the politics of dengue control and daily life in VillavicencioColombia. Soc Sci Med. 2005;61:495-502. https://doi.org/10.1016/j.socscimed.2004.11.069

13. Madeira NG, Macharelli CA, Pedras JF, Delfino MC. Educação de escolares de primeiro grau como estratégia no controle do dengue. Rev Soc Bras Med Trop. 2002;35:221-6. https://doi.org/10.1590/S0037-86822002000300004 
14. Soto-Hernández RJ, Fernández-Cerna EA, Ávila-Montes GA. Evaluación de un programa educativo sobre dengue y Aedes aegypti focalizado en niños de escuela primaria. Revista Médica Hondureña. 1995;63:12-8.

15. Restrepo BN, Pineda J, Parra-Henao GJ. Aplicación y evaluación de materiales educativos para la prevención del dengue en una institución educativa de Medellín, Colombia. Revista CES Medicina. 2011;25:31-41.

16. Ávila Montes GA, Martínez M, Sherman C, Fernández-Cerna E. Evaluación de un módulo escolar sobre dengue y Aedes aegypti dirigido a escolares en Honduras. Rev Panam Salud Pública. 2004;16:84-94.

17. Olano VA, Matiz MI, Lenhart A, Cabezas L, Vargas SL, Jaramillo JF, et al. Schools as potential risk sites for vector-borne disease transmission: Mosquito vectors in rural schools in two municipalities in Colombia. J Am Mosq Control Assoc. 2015;31:212-22. https://doi.org/10.2987/moco-31-03-212-222.1

18. Overgaard HJ, Alexander N, Matiz MI, Jaramillo JF, Olano VA, Vargas S, et al. A clusterrandomized controlled trial to reduce diarrheal disease and dengue entomological risk factors in rural primary schools in Colombia. PLoS Negl Trop Dis. 2016;10:e0005106. https://doi.org/10.1371/journal.pntd.0005106

19. Departamento Administrativo Nacional de Estadística (DANE). Perfil municipal de Anapoima. Censo General, 2005. Accessed on: September 13, 2018. Available at: https://www.dane.gov.co/files/censo2005/perfiles/cundinamarca/anapoima.pdf

20. Departamento Administrativo Nacional de Estadística (DANE). Estimación y proyección de población nacional, departamental y municipal por sexo, grupos quinquenales de edad y edades simples de 0 a 26 años 1985-2020. Accessed on: September 13, 2018. Available at: https://www.dane.gov.co/index.php/estadisticas-por-tema/demografia-y-poblacion/ proyecciones-de-poblacion

21. Departamento Administrativo Nacional de Estadística (DANE). Perfil municipal La Mesa. Censo general 2005. Accessed on: September 13, 2018. Available at: https://www.dane.gov. co/files/cens02005/perfiles/cundinamarca/la mesa.pdf

22. Ministerio de Salud. Resolución 8430 de 1993. Accessed on: September 13, 2018. Available at: https://www.minsalud.gov.co/sites/rid/Lists/BibliotecaDigital/RIDE/DE/DIJ/RESOLUCION8430-DE-1993.PDF

23. Yboa BC, Labrague LJ. Dengue knowledge and preventive practices among rural residents in Samar province, Philippines. Am J Public Health. 2013;1:47-52. https://doi.org/10.12691/ajphr-1-2-2

24. Torres-López TM, Guerrero-Cordero JL, Salazar-Estrada JG. Dimensiones culturales del dengue que favorecen o dificultan su prevención en México. Rev Panam Salud Pública. 2012;31:197-203.

25. Lefèvrel AM, Ribeiroll AF, Monteiro Marques II GR, Serpall LL, Lefèvrelll F. Representações sobre dengue, seu vetor e ações de controle por moradores do município de São Sebastião, litoral Norte do Estado de São Paulo, Brasil. Cad Saúde Pública. 2007;23:1696706. https://doi.org/10.1590/S0102-311X2007000700022

26. Ministerio de la Protección Social, Instituto Nacional de Salud, Organización Panamericana de la Salud. Gestión para la vigilancia entomológica y control de la transmisión de dengue. Bogotá: Ministerio de la Protección Social, Instituto Nacional de Salud, Organización Panamericana de la Salud; 2010.

27. Instituto Nacional de Salud. Reporte de evento. Comportamiento epidemiológico del dengue en Colombia año 2011. Accessed on: September 11, 2018. Available at: http://portalsivigila. ins.gov.co/rutinaria/historica/rutinaria 2011.xIsx

28. Universidad El Bosque. Prevención del dengue y control del Aedes aegypti en el área rural del municipio de Anapoima, Cundinamarca. Resultados del diagnóstico. Bogotá: Instituto Salud y Ambiente, Universidad El Bosque; 2011.

29. Al-Dubai SA, Ganasegeran K, Mohanad Rahman A, Alshagga MA, Saif-Ali R. Factors affecting dengue fever knowledge, attitudes and practices among selected urban, semiurban and rural communities in Malaysia. Southeast Asian J Trop Med Public Health. 2013;44:37-49.

30. Torres JL, Ordóñez JG, Vázquez-Martínez MG. Dengue-related knowledge, attitudes, and practices in primary schools in Tapachula, Chiapas, México. Rev Panam Salud Pública. 2014;35:214-8. 
31. Alcalá L, Quintero J, González-Uribe C, Brochero H. Productividad de Aedes aegypti (L.) (Diptera: Culicidae) en viviendas y espacios públicos en una ciudad endémica para dengue en Colombia. Biomédica. 2015;35:258-68. https://doi.org/10.7705/biomedica.v35i2.2567

32. Departamento Administrativo Nacional de Estadística (DANE). Encuesta de Calidad de Vida - ECV 2015. Boletín técnico. Accessed on: September 11, 2018. Available at: https:// www.dane.gov.co/files/investigaciones/condiciones vida/calidad vida/Boletin Tecnico ECV_2016.pdf

33. Vesga-Gómez C, Cáceres-Manrique FM. Eficacia de la educación lúdica en la prevención del dengue en escolares. Rev Salud Pública. 2010;12:558-69.

34. Santos SL, Parra-Henao G, Silva MB, Augusto LG. Dengue in Brazil and Colombia: A study of knowledge, attitudes, and practices. Rev Soc Bras Med Trop. 2014;47:783-7. https://doi.org/10.1590/0037-8682-0048-2014

35. Ministerio de la Protección Social, Instituto Nacional de Salud, Organización Panamericana de la Salud. Protocolo para la vigilancia en salud pública del dengue. Bogotá: Ministerio de la Protección Social, Instituto Nacional de Salud, Organización Panamericana de la Salud; 2010.

36. Spiegel J, Bennett S, Hattersley L, Hayden MH, Kittayapong P, Nalim S, et al. Barriers and bridges to prevention and control of dengue: The need for a social-ecological approach. EcoHealth. 2005;2:273-90. https://doi.org/10.1007/s10393-005-8388-x 